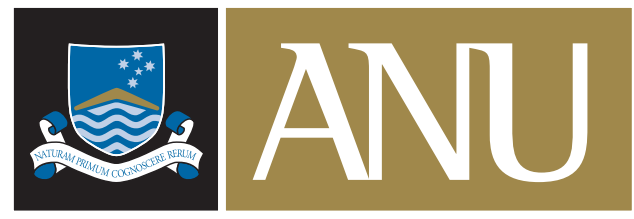

THE AUSTRALIAN NATIONAL UNIVERSITY

Working Papers in

Trade and Development

\begin{tabular}{|} 
East Asia in World Trade: \\
The Decoupling Fallacy, Crisis and \\
Policy Challenges \\
Prema-chandra Athukorala \\
and \\
Archanun Kohpaiboon \\
July 2010 \\
Working Paper No. 2010/05
\end{tabular}

The Arndt-Corden Division of Economics Crawford School of Economics and Government ANU College of Asia and the Pacific 



\title{
East Asia in World Trade: The Decoupling Fallacy, Crisis and Policy Challenges
}

\author{
Prema-chandra Athukorala \\ The Arndt-Corden Division of Economics \\ Crawford School of Economics and Government \\ The College of Asia and the Pacific \\ The Australian National University \\ And \\ Archanun Kohpaiboon \\ Faculty of Economics \\ Thammasat University, Bangkok
}

Corresponding Address :

Prema-chandra Athukorala

The Arndt-Corden Division of Economics

Crawford School of Economics and Government

The College of Asia and the Pacific

Coombs Building 9

The Australian National University

Canberra ACT 0200

\section{Email: Prema-chandra.Athukorala@anu.edu.au}

July 2010

Working paper No. 2010/05 
This Working Paper series provides a vehicle for preliminary circulation of research results in the fields of economic development and international trade. The series is intended to stimulate discussion and critical comment. Staff and visitors in any part of the Australian National University are encouraged to contribute. To facilitate prompt distribution, papers are screened, but not formally refereed. 


\title{
East Asia in World Trade: The Decoupling Fallacy, Crisis and Policy Challenges
}

\author{
Prema-chandra Athukorala \\ Arndt-Corden Division of Economics \\ Crawford School of Economics and Government \\ Australian National University \\ and \\ Archanun Kohpaiboon \\ Faculty of Economics \\ Thammasat University, Bangkok
}

\begin{abstract}
This paper examines the export experience of China and other East Asian economies in the aftermaths of the global financial crisis against the backdrop of pre-crisis trade patterns. The analysis is motivated by the 'decoupling' thesis, which was a popular theme in the Asian policy circles in the lead-up to the onset of the recent financial crisis, and aims to probe three key issues: Was the East Asian trade integration story that underpinned the decoupling thesis simply a statistical artifact or the massive export contraction caused by an overreaction of traders to the global economic crisis and/or by the drying up of trade credit, which overpowered the cushion provided by intra-regional trade? What are the new policy challenges faced by the East Asian economies? Is there room for an integrated policy response that marks a clear departure from the pre-crisis policy stance favoring export-oriented growth? The findings caution against a possible policy backlash against openness to foreign trade arising from the new-found enthusiasm for rebalancing growth, and make a strong case for a long-term commitment to non-discriminatory multilateral and unilateral trade liberalization.
\end{abstract}

JEL classification: $\quad$ F15, F23, O53

Key words:

global financial crisis, global production sharing, production networks, China 


\section{East Asia in World Trade: The Decoupling Fallacy, Crisis and Policy Challenges}

The 'decoupling' thesis, the notion that the East Asian region has become a self-contained economic entity with potential for maintaining its own growth dynamism independent of the economic outlook for the traditional developed market economies, was a popular theme in Asian policy circles in the first decade of the new millennium until the onset of the recent financial crisis. ${ }^{1}$ The empirical basis for this was provided by studies of trade patterns based on readily available trade data, which revealed a continuous increase in trade among the countries in the region (intra-regional trade) since the late 1980s, a process which received added impetus from the subsequent emergence of China as a world export powerhouse. A few studies questioned the validity of this inference in a context where international production fragmentation and the related network trade had been rapidly expanding with East Asia as its centre of gravity (Roach 2009: Ch. 1; Bergsten et al. 2006, Athukorala 2005, Garnaut 2003). However, the decoupling thesis continued to dominate the policy scene, presumably because it fitted well with the East Asian growth euphoria of the day.

The global financial crisis (GFC) has served to reveal the fragility of the decoupling thesis since all major East Asian countries, including China, have experienced precipitous trade contractions. Consequently, the policy debate in East Asia has made a U-turn from the complacency of the decoupling thesis to call for the rebalancing of East Asian growth with a view to reducing its susceptibility to the vicissitudes of the global business cycle (ADB 2010, IMF 2010).

What went wrong with the decoupling thesis? Was the trade integration story that underpinned the decoupling thesis simply a statistical artifact, resulting from a failure to incorporate the realities of an era of global production sharing? What are the policy challenges faced by the East Asian economies in the post-GFC era? Is there room for an integrated policy response that marks a clear departure from the pre-crisis policy stance favouring outward-oriented development strategies? This chapter aims to probe these

\footnotetext{
${ }^{1}$ See Urata (2006), Yoshitomi (2007) and Park and Shin (2009) and the works cited therein.
} 
and related issues through a comparative analysis of the export experiences of China and other East Asian economies in the aftermath of the crisis against the backdrop of a systematic analysis of pre-crisis trade patterns.

The decoupling thesis is based on the traditional notion of horizontal specialisation according to which international trade is an exchange of goods that are produced from start to finish in just one country. It ignores the implications for trade flow analysis of the ongoing process of global production sharing ${ }^{2}$ — the breakup of the production processes into separated stages, with each country specializing in a particular stage of the production sequence - and the increasingly important role played by China and other East Asian countries in the resultant global production network. In a context where production-sharing based trade is growing rapidly, trade flow analysis based on the assumption of horizontal specialisation can lead to misleading inferences about the nature and extent of trade integration among countries for three reasons.

First, in the presence of global production sharing, trade data are double-counted because goods in process cross multiple international borders before becoming embodied in the final product. Thus, the total amount of recorded trade could be a multiple of the value of final goods. Second, and perhaps more importantly, trade shares calculated using reported data can lead to wrong inferences as to the relative importance of the 'region' and the rest of the world for the growth dynamism of a given country, even controlling for double counting in trade. This is because 'fragmentation trade' and trade in related final goods ('final trade') are unlikely to follow the same patterns. Third, the intra-regional trade ratio estimated by lumping imports and exports tends to hide a significant asymmetry in regional trade patterns of imports and exports in a context where network related trade is growing rapidly.

Given these concerns, a meaningful analysis of trade patterns requires systematic separation of parts and components (henceforth referred to as 'components' for short) from final (assembled) products in reported trade data. We do this through a careful disaggregation of trade data based on the Revision 3 of the Standard International Trade Classification (SITC, Rev 3) extracted from the United Nations trade data reporting

${ }^{2}$. In the recent literature, an array of alternative terms have been used to describe this phenomenon, including 'international production fragmentation', 'vertical specialisation', 'slicing the value chain' and 'outsourcing'. 
system (UN Comtrade database). ${ }^{3}$

For the purpose of this paper, East Asia (EA) is defined to include Japan and developing East Asia (DEA), which covers the newly industrialized economies (NIEs) of North Asia (South Korea, Taiwan and Hong Kong), China and members of the Association of Southeast Asian Nations (ASEAN). Among the ASEAN countries, Myanmar is not covered because of a lack of data and Brunei, Cambodia and Laos are treated as a residual group because of data gaps. The East Asian experience is examined in the wider global context, focusing specifically on the comparative experiences of the North American Free Trade Agreement (NAFTA) and the European Union (EU).

The paper is structured as follows. The first section examines trade patterns in East Asia in the global context, paying attention to the nature and extent of production sharing and network-based trade, East Asia's role in this new form of international exchange and its implications for regional versus global economic integration. In the next section the latest available data are used to examine the impact of the GFC on the export performance of East Asian economies. The following section deals with postcrisis policy challenges, focusing on the emerging debate regarding rebalancing (or reshaping) development strategies. The final section summarises the key findings and draws some general inferences.

\section{Pre-crisis Trade patterns}

Rapid export growth has been the hallmark of East Asia's rise in the global economy. The combined share of East Asian countries in world non-oil exports recorded a three-fold increase between 1969/70 and 2006/7 from 11 percent to 33 percent. ${ }^{4}$ The region accounted for over 40 percent of the total increment in world exports over this period. In the 1970s and 1980s, Japan dominated the region's trade, accounting for nearly 60 percent of its exports and imports. The picture has changed dramatically over the past two

\footnotetext{
${ }^{3}$ For details on the decomposition procedure, and the list of parts and components used in the analysis, see Athukorala (2009c).

${ }^{4}$ Trade magnitudes throughout the paper are measured in current US dollars unless otherwise indicated. Inter-temporal comparison calculations are made for the two-year averages relating to the end points of the period under study, so as to reduce the impact of year to year fluctuations of trade flows. All data reported, unless otherwise stated, are compiled from the UN Comtrade database.
} 
decades with the share of developing East Asian countries increasing rapidly in the face of a relative decline is Japan's position in world trade. By the middle of this decade these countries accounted for over 80 percent of total regional trade. The rise of China has been the dominant factor behind this structural shift, ${ }^{5}$ but the other countries in the region (Taiwan, Korea, Malaysia, Singapore, the Philippines, Thailand, and more recently Vietnam) have also increased their world market shares.

Rapid export growth in East Asia has been underpinned by a pronounced shift in the region's export structure away from primary commodities and toward manufacturing. By 2005/7 manufacturing accounted for 92 percent of total exports from Asia, up from 78 percent four decades ago. Within manufacturing, machinery and transport equipment (SITC 7), particularly information and communication technology (ICT) products and electrical goods, have played a pivotal role in this structural shift. The share of Asia in world machinery and transport equipment exports increased from 14.5 percent in 1994/5 to 42.4 percent in 2006/7, with DEA accounting for over four-fifths of the increment. By 2006/7, over 58 percent of total world ICT exports originated from Asia, with China alone accounting for 23 percent (Table 1). In electrical goods, China's world market share increased from 3.1 percent to 20.6 percent between these two years. Export dynamism in these product lines has been driven by the ongoing process of global production sharing and the increasingly deep integration of East Asian countries into global production networks.

\section{Table 1 about here}

\section{Table 2 about here}

The best available indicator of the intensity of global production sharing is the share of parts and components in total manufacturing trade. ${ }^{6}$ Reflecting the rapid growth of global production sharing, the share of components in manufacturing trade has sharply increased across all major countries in the region (Table 2). In 2006/7 components

\footnotetext{
${ }^{5}$ For details on China's rise as a major trading nations and its implications for the other countries in the region, see (Athukorala 2009a and 2009b )

${ }^{6}$ Henceforth, for the sake of brevity, we use the term 'components' in place of 'parts and components'.
} 
accounted for 34.1 percent of East Asia manufacturing exports (42.1 percent of manufacturing imports) compared to a world average of 27.1 percent (27.3 percent of imports). The share of components is particularly high among the ASEAN countries. There is a remarkable similarity in component share figures in both exports and imports across countries, reflecting overlapping specialisation patterns in component assembly among countries in the region.

The rapid increase in the component intensity (percentage shares of parts and components) in East Asian trade is closely associated with cross-border component trade within regional production networks. As can be seen in Table 3, components account for a much larger share in intra-regional trade in East Asia compared to these countries' shares of world trade and trade with EU and NAFTA. Moreover, the share of components in total intra-regional imports is much larger than in exports, and has increased at a faster rate. This reflects the fact that the region relies more on the rest of the world as a market for final goods than as a market for components. Within East Asia, ASEAN countries stand out for the high share of components in their intra-regional trade flows (over 60 percent in 2006/7). According to country-level data, the share of components in manufacturing exports and imports amounted to over four-fifths in Singapore, Malaysia and the Philippines and over two-thirds in Thailand. South Korea and Taiwan are also involved in sizeable trade in components with other countries in the region. In 20067 components accounted for 59.2 percent and 74 percent of China's imports from developing Asia and ASEAN countries compared to 44 percent in total imports.

\section{Table 3 about here}

\section{China in East Asia Trade}

Manufacturing products dominate China-East Asian trade flows, accounting for nearly 90 percent of both imports and exports (Table 4). In China's total manufacturing imports from East Asia, the share of components increased from 18 percent in 1994/5 to over 44 percent in 2006/7. Within manufacturing, the share of components is much larger in machinery and transport equipment imports, at nearly three-quarters in 2006/7. The shares of components in manufacturing exports also have increased over the years, but 
the magnitudes are significantly lower compared to those in total imports. Interestingly, although China's importance as a market for the rest of East Asia has increased during the period under study (see below), the importance of the region for China's export expansion has declined notably, as it only absorbed 33.7 percent of China's total merchandise exports in 2006/7, down from 55.8 percent in 1993. East Asia's share in China’s total imports increased marginally from 21.3 percent in 1992/3 to 28.8 percent in 2006/7.

\section{Table 4 about here}

\section{Table 5 about here}

Table 5 summarises data on China-East Asian trade relations at the individual country level. Data on the geographic profile of China's manufacturing imports from the region are in Panel A. Panel B gives data on the relative importance of China as an export destination of the East Asia economies. Nearly 60 percent of China's manufacturing imports originate in East Asia. The bulk of these imports come from Japan, Korea and Taiwan. The share of imports coming from the other East Asian countries is small, although growing fast. In 2007 China accounted for only 21.2 percent of total manufacturing exports from the rest of East Asia. At the individual country level, China accounted for 33 percent and 27 percent of exports from Taiwan and Korea respectively. China was also one of the most important export destinations of the Philippines, accounting for more than one fifth of total exports. For all other ASEAN countries, the figures are much smaller, varying from 8 percent to 13.5 percent. Clearly, aggregate data hide some significant differences among East Asian countries in trade links with China, with China's intra-regional trade being largely concentrated in trade with Japan, Korea and Taiwan.

\section{Intra-regional trade patterns}

The previous section reveals three important features of the emerging trade patterns in East Asia compared to overall patterns of global trade. First, component trade has played a more important role in trade expansion in East Asia. Second, trade in components 
accounts for a much larger share in intra-regional trade than is the case for the rest of the world. Third, China's rapid trade expansion largely reflects its role as an assembly centre within global production networks; China's trade links with the rest of East Asia are dominated by components for assembling final products which are predominantly destined for markets in the rest of the world. Given these three peculiarities, conventional trade-flow analysis is bound to yield a misleading picture as to the relative importance of intra-regional trade, as compared to global trade, for growth in East Asia.

To illustrate this point, intra-regional trade shares are estimated separately for total manufacturing, components, and final goods (total manufacturing net of components), and reported in Table 6. The table covers trade in East Asia and three subregions therein which relate to contemporary Asian policy debates on regional integration. Data for NAFTA and EU are reported for comparative purposes. Estimates are given for total trade (imports + exports) as well as for exports and imports separately in order to illustrate possible asymmetries in trade patterns resulting from East Asia's increased engagement in fragmentation-based international exchange. ${ }^{7}$

\section{Table 6 about here}

Trade patterns depicted by the unadjusted (standard) trade data affirm the perception underlying the decoupling thesis that Asia, and in particular East Asia, has become increasingly integrated through merchandise trade. In 2006/7 intra-regional trade accounted for 55.1 percent of total manufacturing trade, up from 35.8 percent in 1986/7. The level of intra-regional trade in East Asia was higher than that of NAFTA throughout this period and was rapidly approaching the level of the EU-15. For developing East Asia (Asia excluding Japan) and ASEAN +3, the ratios are lower than the aggregate regional figure, but they have increased at a much faster rate. The intra-regional trade share of ASEAN has been much lower compared to the other two sub-regions.

However the picture changes significantly when components are netted out: the intra East Asian share in final trade in 2006/7 was 46.4, down from 50.3 percent in

\footnotetext{
7 Disaggregated data needed for separating parts and components from total (reported) trade are available only from 1992 (Athukorala 2009b).
} 
1992/3. The estimates based on unadjusted data and data on final trade are vastly different for East Asia, particularly for DEA and ASEAN. Both the level of trade in the two given years and the change over time in intra-regional trade shares are significantly lower for estimates based on final trade. Interestingly, we do not observe such a difference in estimates for NAFTA and EU.

The intra-regional shares calculated separately for imports and exports clearly illustrate the risk of making inferences about regional trade integration based on total (imports + exports) data. There is a notable asymmetry in the degree of regional trade integration in East Asia. Unlike in the EU and NAFTA, in East Asia the increase over time in the intraregional trade ratio (both measured using unadjusted data and data for final trade) has emanated largely from the rapid increase in intra-regional imports; the expansion in intra-regional exports has been consistently slower. The dependence of East Asia (and country sub-groups therein) on extra-regional markets (in particular those in NAFTA and EU) for export-led growth is far greater than is revealed by the standard intra-regional trade ratios commonly used in the debate on regional economic integration. For instance, in 2007 only 43.9 percent of total East Asian manufacturing exports was absorbed within the region, compared to an intra-regional share of 64.4 percent in total manufacturing imports. For DEA the comparable figures were 33.4 percent and 46.7 percent respectively. This asymmetry is clearly seen across all sub-regions within East Asia. The asymmetry between intra-regional shares of import and exports is much sharper when components are netted out. This is understandable given the heavy 'component bias' in Asian intra-regional trade and the multiple border-crossing of parts and components within regional production networks. On the export side, the intraregional share of final goods declined continuously from 46 percent in 1995 to 37 percent in 2007, whereas intra-regional import share increased from 56 percent to 63 percent between these two time points.

In sum, these data support the hypothesis that, in a context where global production sharing is expanding rapidly, standard trade flow analysis can generate misleading inferences regarding the process of economic integration through trade. When data on assembly trade are excluded from trade flows, these estimates suggest that extraregional trade is much more important than intra-regional trade for continued growth in 
East Asia, whether or not Japan is included. Thus the rising importance of product fragmentation seems to have strengthened, rather than weakened, East Asia's link with the wider global economy. As we will see in the next section, this inference is basically consistent with the behavior of trade flows in East Asia following the onset of the GFC.

\section{Trade performance in the aftermath of the crisis}

A striking feature of the global economy following the onset of the in late 2007 GFC has been the precipitous drop in global trade at a faster rate than during the Great Depression (Almunia et al. 2010, Krugman 2009). From April 2008 to June 2009 world trade contracted by about 20 percent which amounted to almost the total contraction in world trade during the first thirty months of the Great Depression (starting in April 1929). ${ }^{8}$ Interestingly, the trade contraction experienced by the East Asian countries during this period has been even greater than the contraction in total world trade (Figure 1, Table 7).

\section{Figure 1 about here}

Table 7 about here

Krugman (2009) points to the increased vertical integration of global production (the rise of globe production sharing) as a possible explanation for the surprisingly large trade contraction in the present crisis compared to the Great Depression. Vertical integration of production implies that a given degree of contraction in demand for a final (assembled) product has ramifications over trade flows between the many countries involved in the production chain. Also, demand for components is susceptible to rapid stock adjustment by producers compared to final goods. Given that global production sharing is much more important for trade expansion in East Asia, this explanation also seems relevant for East Asia's greater trade contraction compared to overall trade contraction at the global level. However, a number of other factors are also relevant for explaining the larger contraction in trade volume in the current crisis. These include the

\footnotetext{
${ }^{8}$ Numbers derived from Figure 5 in Almunia et al. (2010).
} 
much larger contraction of trade credit, a greater share of consumer durables in contemporary world trade compared to the 1930s, and the effect of recent advances in communication technology on inventory cycle and just-in-time procurement practices. The current state of data availability does not permit us to systematically delineate the impact of production sharing on trade contraction while appropriately controlling for these other possible factors. Instead, this section puts together some readily available data that have some bearing on this issue in order to set the stage for further analysis.

All major East Asian countries (including China which was expected by the decoupling enthusiast to cushion the rest of East Asia against a global economic collapse) experienced a precipitous trade contraction from about the last quarter of 2008 (Table 7). The remarkably synchronized nature of the trade contraction across countries in the region, both in imports and exports, is generally consistent with the close trade ties among the East Asian countries forged within regional production networks and the unique role of the region within global production networks.

Among the East Asian countries Japan has been by far the worst hit. A large share of Japan's exports consists of capital goods and high-end durable consumer goods, such as cars and electrical machinery, machine tools and their components. Exports of capital goods and high-end consumer durables are heavily concentrated in the US and other developed-country markets and are therefore directly exposed to the global economic decline. On the other hand, contrary to the predictions of the decoupling enthusiasts, Japan's growing exports to China have been indirectly affected by declining final (assembled) exports from China (Fukao and Yuan 2009). The degree of export contraction suffered by Taiwan and Korea has been smaller compared to Japan but, on average, notably higher compared to the other East Asian countries. As in the case of Japan, growing exports to China do not seem to have provided a cushion against collapse in world demand for these two countries. The relatively lower degree of export contractions experienced by Korea, Taiwan and the second-tier exporting countries in the region compared to Japan could possibly reflect consumer preferences for pricecompetitive low-end products in the crisis context.

An inspection of growth rates of exports of individual East Asian countries by destination provides no support for the view that East Asian economies have become less 
susceptible to the world-wide trade contraction because of regional growth dynamism. ${ }^{9}$ Intra-East Asia trade flows have in general contracted at a faster rate compared to these countries exports to the USA and EU.

Exports to China from most countries in the region have contracted at a much faster rate compared to their imports from China, perhaps an indication of destocking of components by Chinese firms given the gloomy outlook for exports (Table 8). China's imports from Japan, Korea and Taiwan have shrunk more rapidly (at an average rate of 23.5 percent) than imports from other countries. This is not surprising, given the dominant role played by the former countries in the supply of components to ICT assembly activities in China which are heavily exposed to contractions in import demand in the USA and other developed countries. Overall China's imports from countries in the region intra-regional imports have contracted at a much faster rate compared to her imports from the USA and EU.

\section{Table 8 about here}

Table 9 about here

Date on export growth by major commodity category for import and export of China are summarised in Table 9. A notable pattern is the relatively sharper contraction in the category of machinery exports (in which network trade is heavily concentrated) compared to other product categories, in particular traditional labour-intensive products (textile and garments, footwear and other miscellaneous manufactures). Exports belonging to this commodity category, in particular ICT products and consumer electronics are also predominantly consumer durables which, as already noted, are generally more susceptible to income contraction. In traditional labour-intensive products, developing country producers have the ability to perform better purely on the basis of cost competitiveness even in a context of depressed demand.

\footnotetext{
${ }^{9}$ This inference is based on monthly exports data extracted from the CIEM database (not reported here for want of space).
} 


\section{Policy options}

At the time of writing this paper (mid June 2010) 'the global recovery is proceeding better than expected' (IMF 2010, p. 1). Industrial production in the United State and other major developed countries has begun to recover and the downward spiral in world trade volume has abated. However the economic forces unleashed by the crisis will probably run rampant for years. The recovery has so far been driven largely by unprecedented fiscal and monetary stimulus and there is considerable downside risk of sustainability stemming from fiscal fragility. Over the medium term the US and other crisis affected developed countries will have to save more and spend less in order to wind down the massive accumulated household and public debts. Given this global economic outlook, what are the policy options available to governments in China and other East Asian countries which have depended largely on exports driven growth?

There has been a growing emphasis in Asian policy circles on the need for rebalancing growth — engineering a structural shift in aggregate demand away from exports and towards domestic markets (ADB 2010). The policy measures under consideration include measures to redress the export bias in the incentive structure, to reduce high saving propensities with a view to boosting domestic consumer demand and other measured directly aimed at promoting domestic non-tradable (services) production. The major focus of this policy advocacy is on China.

China's degree of export dependence is unusually high for a continental economy of China's size. China's export to GDP ratio (around 40 percent) grossly exaggerates its export dependence because of the heavy import dependence of assembly exports which accounts for over two thirds of total merchandise exports. However, even the available adjusted estimates (around 20 percent) seem too high for China's potential economic size. Moreover the unusually high domestic saving rates, the vast population base, highly repressed domestic financial system, excessively high (massive) urban-rural household income gap, all indicate the vast potential for policy-induced domestic demand-led growth in China. Growth rebalancing will not only enable China to deal effectively with massive external imbalances while cushioning growth momentum against external 
demand shocks, but also to engineer a critical shift in the focus of national development policy from the quantity to the quality of growth, with a view to redressing urban-rural disparities and achieving social harmony.

The need for embarking on a major structural transition from export-led to domestic-demand led growth was recognized by the Chinese leadership the well before the onset of the global financial crisis (Roach 2009, 229-233). The $11^{\text {th }}$ Five-Year Plan enacted in March 2006 stressed the imperatives of an enhanced, broad-based social safety net (encompassing not just social security but also rural health care and education) to improve income security, thereby reducing the excess precautionary saving that continue to inhibit the expansion of private consumption. However, Chinese authorities have so far failed to put this policy into action, presumably because of the strong domestic political pressure to maintain the momentum of employment-intensive growth through export orientation (Yu 2007, Gan 2008).

The success on the rebalancing front will naturally involve an appreciation of China's real exchange rate ${ }^{10}$, a reduction in profitability of tradable production relatively non-tradable production. But this is unlikely to impede, at least over the medium term, China's role as the premier assembly centre within regional production networks. Even after three decades of rapid growth, the average hourly wage rate for the overall Chinese manufacturing (\$3.2) is still (as at 2007) amounts to only $13 \%$ of the US hourly wage rate (\$24.4). ${ }^{11}$ About half of China’s massive labour force (about 745 million) is still engaged in agriculture where productivity is, on average, barely one-eighth of that in industry and about a quarter of that in the service sector. This, coupled with the high skilled-unskilled wage differential (which, according to some estimates, has risen from 1.3 to 2.1 over the past decade (Blanchard and Giavazzi 2006)) suggest that China still has much potential for moving unskilled workers out of agriculture and into manufacturing and other productive urban sector activities. ${ }^{12}$

\footnotetext{
${ }^{10}$ Whether it would be preferable to achieve this by adjustments to nominal exchange rate than by adjustment to domestic prices remain a subject of controversy which is beyond the scope of this paper.

${ }^{11}$ Data from the US Bureau of Labor Statistics website (ftp.bls.gov)

${ }^{12}$ In recent years there have been many scattered cases of rising wages and worker shortages in industrial cities in China. However, one cannot realistically infer this evidence as indicative of a broader macroeconomic trend of emerging labour shortages, given that the Chinese economy is
} 
The pressure for maintaining export competition in a context of slow-growing world demand could provide a fertile setting for the rise of trade friction and protectionism (Bhagwati 1988, Erixon and Razeen 2009). Fortunately, there has not yet been a protectionist backlash in the form of erecting tariff walls as happened during the Great Depression. However, there are already signs of countries increasingly resorting to disguise (or just disguising) means of protection such as filing anti-dumping complains and imposing stringent implementation of technical and sanitary and phytosanitary standards, in addition to the massive financial support extended by the USA and some other countries to automobile manufacturers (Gamberoni and Newfarmer 2009). The number of legislative measured introduced in the US Congress which involve some forms of sanction on China trade have multiplied in recent years (Roach 2009, p. 241). There is therefore a strong case for devising strategies to fight new protectionism as part of a long term commitment to non-discriminatory multilateral and unilateral liberalisation. The Information Technology Agreement which came into force in 1997 seems to be a promising example to follow (Elek 2008). There is also a case for Asia's G20 countries and the ASEAN Secretariat to consolidate their positions against protectionist tendencies. As part of its attempt to keep export markets open, China should not resist the temptation to use export subsidies and other selective policies to support its export sector. In an era of rising unemployment and the resultant backlash against globalisation in the US and other developed countries, such efforts could be a recipe for anti-china trade sanctions.

One option under consideration in Asian policy circles for supporting regional trade growth in face of slow growth in world demand is to form region-wide FTA, encompassing ASEAN, China, Japan and Korea (and possibly India) (Kawai and Wignaraja 2009, ADB 2009). The logic behind this proposal in relation to the net work trade in the region is the following: Trade within global production networks (both in components and final assembly) is generally more sensitive to tariff changes than is final trade (or total trade as captured in published trade data) (Yi 2003). Normally a tariff is incurred each time a good-in-process crosses a border. Consequently, a one percentage point reduction in tariff leads to a decline in the cost of production of a vertically

still a long way away from having a fully functioning labour market. These cases could well reflect skill mismatches and frictional dislocations in a highly imperfect labour market rather than genuine labour shortages. 
integrated good by a multiple of this initial reduction, in contrast to a one per cent decline in the cost of a regular traded good. Tariff reductions may also make it more profitable for goods that were previously produced entirely in one country to become vertically specialized. Consequently, in theory, the trade-stimulating effect of FTAs would be higher for network trade than for normal trade, other things remaining unchanged.

In our view this is a risky strategy, given Asia's heavy reliance on extra regional markets for its export dynamism. Such a move would invite swift retaliation by the US and EU. A firm commitment as part of the FTA to not to increase existing tariff and non-tariff barriers against non-member is unlikely to avert this threat because an Asia-wide FTA, given that it encompasses a number of significant world trading nations, is likely to involve significant trade diversion even under the existing extra-regional tariffs. In any case, the chances of negotiating a region-wide FTA look rather slim in the context of the on-going crisis. In particular, China may not want to get involved in such an endeavor not only because of its new emphasis on domestic-oriented growth but also because of its official commitment to averting protectionist backlashes against its exports from developed countries. ${ }^{13}$ Governments in Southeast Asian countries are also concerned that any region wide attempt to liberalise trade would give unfair advantage to China in attracting FDI involved in global production networks, given its vast domestic economy characterized by regional differences in cost of production. ${ }^{14}$

In reality, the trade effects of any FTA would depend very much on the nature of the rules of origin (ROO) built into it. In particular, there are three main complications involved in bringing network trade under FTAs (or other preferential trading arrangements). First, formulating ROOs for network-related trade is rather complicated business. The conventional value-added criterion is not virtually applicable to this trade because the products involved are low-value added by their very nature. The only viable option is to go for 'change in tariff lines'-based ROOs, but this leads to insurmountable administrative problems because trade in electrical and electronics goods and the related parts and components belong to the same tariff codes at the HS-6 digit level, which is the

\footnotetext{
${ }^{13}$ See for instance the recent article wrote by the Chinese Minister of Trade to the Wall Street Journal ( Demin 2009)

${ }^{14}$ This point is based on interviews with high-ranking officials at the Thai Ministry of Foreign Affairs.
} 
normal base for designing this type of ROOs (Kohpaiboon 2009: Appendix 2). For example, electrical appliances assembly plants is Thailand which use imported bare printed circuit board (BPCB) together with other locally procured electronic components (e.g. diode, integrated circuits, semi-conductors) to printed circuit board assembly (PCBA) for export are not eligible to FTA concessions because BPCBs and PCBAs belong to the same HS code 853690 .

Second, the process of international production fragmentation and the networkbased international production is characterised by the continuous emergence of 'new' products. Given the obvious administrative problems involved in revising ROOs in tandem, these product inventions and innovations naturally opens up room for unnecessary administrative delays and/or tweaking of rules as a means of disguised protection (Elek 2008). Moreover, given the importance of extra-regional markets for final goods for the growth dynamism of production networks in Asia, maintaining barriers to trade against non-members (while allowing free trade among members) can thwart 'natural' expansion of global production sharing. Third, twisting ROOs for the purpose of import-competing industries becomes easier when the production process involves procuring parts and components from a number of sources: tightening ROOs on the procurement of one critical input would suffice to protect competing domestic producers of the final (assembled) product. ${ }^{15}$

Finally, it is important to note that, the available evidence on the operation of FTAs in operation in the region (and beyond) augur well for the potency of a new regionwide FTA. Presumably because of the operational complications noted above, the actual utilization rates of tariff concessions provided under these FTAs are rather low, ranging from about 5 percent to 20 percent across different product categories (Takahasgi and Urata 2008, Kawai and Wignaraja 2009, Kohpaiboon 2008). More importantly, there is

${ }^{15}$ ROOs relating to TV sets (HS852812) in the Thailand-Australia Free Trade Agreements (Annex 4.1) can be used to illustrate this point. To become eligible for preferential tariffs, TV producers must source three parts (HS701120, 854011, and 854091) locally. But TV Picture Tubes (HS854011) are not produced in Thailand and Thai color TV assembly is viable if an only this item is procured from Japan, Taiwan, or Korea. Thus, even though preferential tariff on TV under the FTA (20 percent) is very attractive, Thailand-Australia FTA is virtually irrelevant for TV assembly plants located in Thailand. 
evidence that the utilization rates are often firm/industry specific: Normally Large firms and firms with close trade and FDI ties or those located in particular industries where meeting ROO requirements are simple and straightforward use FTAs. The upshot is that FTAs are unlikely to have the potential to promote trade in a neutral and broad-based fashion.

\section{Conclusions}

Intra-regional trade shares based on conventional trade data are generally consistent with the view that East Asia has become increasingly integrated through merchandise trade. However, when the on-going process of international production fragmentation and East Asia's unique role in China-centered global production networks are appropriately taken into account, it is clearly evident that, the increase over time in intraregional trade ratios has emanated largely from the rapid increase in intra-regional imports, while intraregional export expansion has persistently lagged behind. The asymmetry in intraregional shares between imports and exports is much sharper when reported trade data are adjusted for trade in parts and components. Clearly, the region's dependence of the rest of the world for its trade expansion has in fact increased over the time.

This inference is basically consistent with the behaviour of trade flows following the onset of the global financial crisis. The remarkably synchronised nature of the trade contraction across countries in the region is generally consistent with the close trade ties within East Asian, forged within regional production networks. While many had hoped that China would provide a cushion for this export contraction-as would have been consistent with the decoupling thesis-this did not turn out to be the case.

The rise of global production sharing has strengthened the case for a global, rather than a regional, approach to trade policymaking. Given the global orientation of the region's economies, we question whether there would be any significant positive pay-off from forming a region-wide FTA. It is doubtful whether FTA approach to trade liberalization is feasible in a context where global production networks are rapidly expanding, seamlessly encompassing many industries and countries.

The recent and prospective developments in the global economy following the global financial crisis make a strong case for China to go ahead with the speedy 
implementation of the growth-rebalancing policy embodied it the $11^{\text {th }}$ Five Year Plan. Given the nature of domestic factor market conditions and the on-going changes in the process of global production sharing, promoting domestic demand-oriented growth and engagement in global production sharing are not mutually exclusive policy priorities for China over the medium term. Successful growth rebalancing has the potential to facilitate the further expansion of network trade by averting trade friction with and retaliation from the US and other major trading-partner countries. An enlarged domestic market would also have potential to improve international competitiveness of exporting firms within production networks by reducing unit cost of production. Looking further ahead, increase in domestic income and wages under a successful balanced growth strategy would provide the setting for china to move up the value ladder within global production networks. After all, the bulk (more than 60 per cent) of international exchange within global production networks takes place among developed countries and, in the future, China has the potential to become one of them.

\section{References}

ADB (2009), Asian Development Outlook 2009: Rebalancing Asia’s Growth, Manila: Asian Development Bank.

ADB (2009), Asian Development Outlook 2010: Macroeconomic Management Beyond the Crisis, Manila: Asian Development Bank.

Almunia, Miguel, Austin Benetrix, Barry Eichengreen, Kevin H. O’Rourke and Gisela Rua (2010), 'From Great Depression to Great Credit Crisis: Similarities, Differences and Lessons’, Economic Policy, April 2010, 219-265.

Athukorala, Prema-chandra (2005), 'Product Fragmentation and Trade Patterns in East Asia’, Asian Economic Papers, 4(3), 1-27 ‘

Athukorala, Prema-chandra (2009a), 'The Rise of China and East Asian Export Performance: Is the Crowding-out Fear Warranted?', World Economy, Vol. 32, No. 2, pp. 234-66.

Athukorala, Prema-chandra (2009b), 'China and Southeast Asia in the New Division of Labour', in Linda Yueh (ed.), The Future of Asian Trade and Growth: Economic Development with the Emergence of China, London: Routledge, 406-431. 
Athukorala, Prema-chandra (2009c), 'Production Networks and Trade Patterns:

East Asia in a Global Context', Trade and Development Discussion Paper 2009/08, Division of Economics, Research School of Pacific and Asian Studies, Australian National University (forthcoming in Asian Economic Papers).

Bergsten, C. Fred, B. Gill, N. R. Lardy and D. Mitchell (2006), China: The Balance Sheet, New York: Public Affairs

Blanchard, Oliver and Francesco Giavazzi (2006), 'Rebaancing Growth in China: A Three-Handed Approach', China and World Economy, 14(4), 1-20.

Bhagwati, Jagdish (1988), Protectionism, MA: MIT Press.

Bradsher, Keith (2009), ‘Asia’s’ Trade Slows, China Rethinks its Growth Strategy’, New York Time, 1 January 2009.

Deming, Chen (2009), 'China Calls on the World’s Governments to Learn from History’, Wall Street Journal, 20 February.

Elek, Andrew (2008), 'Immunizing Future Protectionist: Preventing the Emergence of More Sensitive Sectors', Asia Pacific Economic Papers 372, Australia-Japan Research Centre, Australian National University.

Erixson, Fredrik and Razeen Sally (2009), 'Fighting the Urge for Protectionism', Far Eastern Economic Review, 172(1) (Jan/Feb), 28-31.

Fukao, Kyoji and Tangjun Yuan (2009), 'Why is Japan so heavily affected by the global economic crisis?', www.voxeu.org, 8 June.

Gamberoni, Elisa and Richard Newfarmer (2009), 'Trade Protection: Incipient but Worrisome Trends’, www.voxeu.org, 4 March 2009.

Gang, Fan (2008), 'Renminbi Revaluation and US Dollar Depreciation', in Goldstein, Morris and Nicholas R. Lardy (eds.) (2008), Debating China's Exchange Rate Policy, Washington, DC: Peterson Institute for International Economics.

Garnaut, Ross (2003), ‘Australia and Japan: Time to be Important to Each Other Again', Address to the Australia-Japan Business Committee conference, Kyoto, 5 October 2003.

IMF (2010), Global Economic Outlook: Rebalancing Growth, Washington DC: IMF.

Kawai, Masahiro and Ganesh Wignaraja (2008), 'Multilateralising Regional Trading Agreements in Asia', in Richard Baldwin and Patrick Low (eds.), 
Multilateralizing Regionalism: Challenges for the Global Trading System, Cambridge: Cambridge University Press.

Kawai, Masahiro and Ganesh Wignaraja (2008), 'The Asian Noodle Bowl: Is It Serious for Business?', ADBI Working Paper 136, Tokyo: Asian development Bank Institute.

Krugman, Paul (2009), 'The Return of Depression Economics', Lionel Robbins Lecture (PPT presentation and th summary by Geoff Riley, 'Paul Krugman at LSE), http/cep.lse.ac.uk/_new/events/special_post.asp.

Kohpaiboon, Archanun (2008) 'Exporters' Response to AFTA Tariff Preferences: Evidence from Thailand' Paper presented at the East Asian Economic Congress, Manila.

Park, Yung Chul and Kwanho Shin (2009) Economic Integration and Changes in the Business Cycle in East Asia: Is the Region Decoupling from the Rest of the World?. Asian Economic Papers 8(1), 107-140

Roach, Stephen (2009), The Next Asia: Opportunities and Challenges for a New Globalization, Hoboken, NJ: John Wiley, 172-188.

Takahashi, Katsudide and Shujiro Urata (2008), 'On the Use of FTAs by Japanese Firms', RIETI Discussion Paper o8-E-002, Graduate School of Asia-Pacific Studies, Waseda University.

Urata, Shujiro (2006), “A Shift from Market-driven to Institution-driven Regionalization in East Asia." Paper presented to Conference on Economic Policy Reform in Asia, June, Stanford University.

Yoshitomi, Masaru (2007), 'Global Imbalances and East Asian Monetary Cooperation', in Duck-Koo Chung and Barry Eichengreen (eds.), Towards and East Asian Exchange Rate Regime, Washington DC: Brookings Institution Press, 22-48.

Yi, Kei-Mu (2003), 'Can Vertical Specialization Explain the Growth of World Trade', Journal of Political Economy, 111(1), 52-102.

Yu, Yongding (2007), 'Global Imbalances and China', The Australian Economic Review, vol.40: pp.3-23. 
Table 1: Composition of Manufacturing Exports ${ }^{1}, 2006 / 7$ ( percent)

\begin{tabular}{|c|c|c|c|c|c|c|c|c|c|}
\hline Commodity group ${ }^{2}$ & EA & Japan & $\overline{\text { DEA }}$ & China & $\mathrm{TW}+\mathrm{K}$ & ASEAN & NAFTA & EU15 & World \\
\hline Chemicals (SITC 5) & 0.1 & 0.1 & 0.1 & 0.1 & 0.1 & 0.0 & 0.2 & 0.2 & 0.2 \\
\hline Resource based products（SITC 6 - SITC 68) & 1.2 & 1.8 & 0.9 & 1.0 & 1.0 & 0.7 & 2.1 & 2.8 & 2.0 \\
\hline Machinery and transport equipment (SITC 7) & 89.7 & 87.5 & 90.3 & 91.6 & 84.0 & 94.7 & 86.0 & 87.9 & 88.1 \\
\hline Power generating machines (SITC 71) & 1.8 & 3.8 & 1.1 & 1.1 & 1.1 & 1.2 & 9.0 & 6.6 & 4.9 \\
\hline Specialized industrial machine (SITC 72) & 2.1 & 3.5 & 1.7 & 1.8 & 1.1 & 2.3 & 2.6 & 3.5 & 2.7 \\
\hline Metal working machine (SITC 73) & 0.3 & 0.6 & 0.2 & 0.2 & 0.3 & 0.1 & 0.4 & 0.7 & 0.5 \\
\hline General industrial machinery (SITC 74) & 1.3 & 1.7 & 1.2 & 1.4 & 0.9 & 1.2 & 2.4 & 3.5 & 2.3 \\
\hline ICT products & 60.5 & 33.2 & 68.9 & 69.2 & 59.7 & 78.3 & 27.6 & 22.9 & 41.1 \\
\hline Office/ automatic data processing machines (SITC 75) & 19.6 & 8.2 & 23.1 & 29.0 & 8.7 & 27.0 & 7.2 & 7.6 & 12.4 \\
\hline Telecommunication and sound recording equipment (SITC 76) & 18.7 & 9.0 & 21.7 & 28.3 & 16.1 & 14.9 & 9.6 & 7.9 & 13.1 \\
\hline Semiconductors and semiconductor devices (SITC772+776) & 22.2 & 16.0 & 24.2 & 11.8 & 34.9 & 36.4 & 10.8 & 7.5 & 15.7 \\
\hline Electrical goods (SITC $77-772-776)$ & 9.7 & 8.1 & 10.2 & 14.2 & 6.1 & 6.4 & 8.2 & 8.5 & 9.3 \\
\hline Road vehicles (SITC 78) & 12.7 & 35.0 & 5.9 & 3.2 & 12.6 & 4.4 & 26.5 & 36.4 & 23.0 \\
\hline Other transport equipment (SITC 79) & 1.3 & 1.6 & 1.2 & 0.7 & 2.3 & 0.9 & 9.3 & 5.7 & 4.4 \\
\hline Miscellaneous manufacturing (SITC 8) & 9.1 & 10.6 & 8.7 & 7.3 & 14.9 & 4.6 & 11.8 & 9.1 & 9.8 \\
\hline Professional and scientific equipment (SITC 87) & 5.5 & 5.8 & 5.4 & 4.0 & 11.0 & 2.6 & 8.2 & 5.9 & 6.3 \\
\hline Photographic apparatus (SITC 88) & 2.3 & 3.6 & 1.9 & 2.4 & 1.2 & 1.3 & 1.3 & 1.8 & 2.1 \\
\hline Total manufacturing exports & 100 & 100 & 100 & 100 & 100 & 100 & 100 & 100 & 100 \\
\hline US $\$$ billion & 1826 & 428 & 1398 & 656 & 359 & 348 & 739 & 1366 & 4517 \\
\hline
\end{tabular}

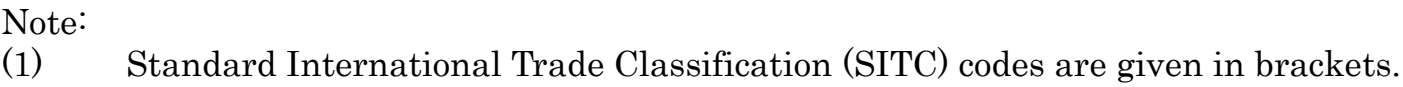

(2) EA: East Asia, DEA: Developing East Asia, TW+K: Taiwan and Korea; ASEAN6: Six main ASEAN countries; EU15: 15 member countries of the European Union; NAFTA: countries in the North American Free Trade Agreement (USA, Canada and Mexico)

Source: Compiled from UN Comtrade database 
Table 2: Share of Parts and Components in Manufacturing Trade, 1992/3 and 2006/7 ( percent)

\begin{tabular}{lrrrr}
\hline & \multicolumn{3}{c}{ Exports } & \multicolumn{3}{c}{ Imports } \\
\hline East Asia & $1992 / 3$ & $2006 / 7$ & $1992 / 3$ & $2006 / 7$ \\
Japan & 20.2 & 34.1 & 27.2 & 42.1 \\
Developing East Asia & 23.9 & 34.4 & 19.3 & 29.9 \\
$\quad$ China (PRC) & 17.3 & 34 & 29 & 44.2 \\
Hong Kong, China & 7.4 & 25.6 & 20.4 & 44 \\
Taiwan & 15.8 & 33.3 & 24.1 & 48.5 \\
Republic of Korea & 24.7 & 44.2 & 29.5 & 38.9 \\
ASEAN & 18.1 & 47.3 & 30.1 & 31.9 \\
Indonesia & 22.7 & 44.2 & 36 & 47.9 \\
Malaysia & 3.8 & 21.5 & 27 & 21.8 \\
Philippines & 27.7 & 53.6 & 40.5 & 50 \\
Singapore & 32.9 & 71.7 & 32.6 & 61.3 \\
Thailand & 29 & 49.3 & 39.9 & 60.4 \\
Vietnam & 14.1 & 29.9 & 30.6 & 36.1 \\
South Asia & --- & 11.0 & --- & 19.1 \\
India & 2.3 & 8.2 & 16.6 & 23.8 \\
NAFTA & 3 & 10.4 & 17.5 & 22.9 \\
Mexico & 28.4 & 31.2 & 37.4 & 28.8 \\
EU15 & 42.1 & 34.6 & 29.4 & 36.1 \\
Developed countries & 18.3 & 22.4 & 21.2 & 23.2 \\
Developing countries & 20.4 & 25.2 & 22.6 & 23.4 \\
World & 14.6 & 29.2 & 11.9 & 33.6 \\
\hline
\end{tabular}

Note: ... Data not available

Source: Compiled from UN Comtrade database 
Table 3: Share of parts and components in bilateral trade flows, 2006/7 (percent)

\begin{tabular}{|c|c|c|c|c|c|c|c|c|}
\hline Reporting country & EA & Japan & DEA & PRC & ASEAN & NAFTA & EU15 & World \\
\hline \multicolumn{9}{|l|}{ (a) Exports } \\
\hline East Asia (EA) & 47.6 & 32.9 & 50.1 & 51.6 & 54.5 & 25.1 & 24.1 & 34.1 \\
\hline Japan & 42.0 & 0.0 & 42.0 & 41.5 & 47.9 & 31.5 & 30.4 & 34.4 \\
\hline Developing East Asia (DEA) & 48.1 & 33.4 & 53.9 & 0.0 & 65.2 & 22.7 & 21.6 & 34.0 \\
\hline China (PRC) & 36.2 & 25.2 & 40.6 & 0.0 & 49.1 & 17.1 & 16.3 & 25.6 \\
\hline Korea & 61.9 & 51.5 & 63.5 & 57.3 & 63.7 & 36.6 & 26.8 & 44.2 \\
\hline Taiwan & 51.5 & 59.0 & 50.5 & 39.5 & 61.2 & 35.0 & 37.6 & 44.2 \\
\hline ASEAN10 & 58.2 & 39.9 & 61.4 & 64.0 & 56.0 & 32.1 & 33.9 & 44.2 \\
\hline NAFTA & 46.7 & 36.5 & 49.8 & 34.8 & 67.9 & 28.8 & 30.6 & 31.2 \\
\hline EU15 & 31.4 & 18.7 & 34.8 & 30.4 & 46.5 & 22.1 & 22.0 & 22.4 \\
\hline \multicolumn{9}{|l|}{ (b) Imports } \\
\hline East Asia (EA) & 51.7 & 48.8 & 52.8 & 34.8 & 68.3 & 54.7 & 33.1 & 42.1 \\
\hline Japan & 34.2 & 0.0 & 34.2 & 23.1 & 44.9 & 41.0 & 18.9 & 29.9 \\
\hline Developing East Asia (DEA) & 55.5 & 47.7 & 59.5 & 0.0 & 74.3 & 40.3 & 31.7 & 44.2 \\
\hline China (PRC) & 55.2 & 47.5 & 59.2 & 0.0 & 74.0 & 40.1 & 31.6 & 44.0 \\
\hline Korea & 33.0 & 26.6 & 38.1 & 26.1 & 55.7 & 38.9 & 22.9 & 31.9 \\
\hline Taiwan & 46.7 & 33.8 & 58.3 & 44.1 & 68.8 & 40.2 & 28.0 & 38.9 \\
\hline ASEAN10 & 50.3 & 47.2 & 51.4 & 40.1 & 55.9 & 67.5 & 41.7 & 47.9 \\
\hline NAFTA & 29.4 & 39.3 & 26.0 & 17.7 & 40.5 & 36.3 & 25.1 & 28.8 \\
\hline EU15 & 25.0 & 33.6 & 22.8 & 14.9 & 37.9 & 34.1 & 22.1 & 23.4 \\
\hline
\end{tabular}

Note:

1. EA: East Asia, DEA: Developing East Asia; ASEAN6: six main ASEAN countries; EU15: 15 member countries of the European Union; NAFTA: countries in the North American Free Trade Agreement (USA, Canada and Mexico)

Source: Compiled from UN Comtrade database. 
Table 4: China's trade with rest of East Asia ( percent)

\begin{tabular}{|c|c|c|c|c|}
\hline & \multicolumn{2}{|c|}{ Exports } & \multicolumn{2}{|c|}{ Imports } \\
\hline A: Commodity composition & $1994-5$ & $2006-7$ & $1994-5$ & 2006-7 \\
\hline A:1: Total trade & 100 & 100 & 100 & 100 \\
\hline Primary products & 16.2 & 10.4 & 23.5 & 13.5 \\
\hline Manufacturing & 83.4 & 89.2 & 76.1 & 86.3 \\
\hline Machinery and transport equipment (SITC 7) & 20.8 & 46.6 & 26.4 & 49.7 \\
\hline Electronics and electrical goods $(75+76+77)$ & 16.7 & 40.6 & 15.0 & 43.0 \\
\hline Miscellaneous manufacturing (SITC 8) & 43.3 & 25.5 & 7.7 & 12.5 \\
\hline Apparel (84) & 18.5 & 10.3 & 1.3 & 0.4 \\
\hline A2: Parts and components & 100 & 100 & 100 & 100 \\
\hline Machinery and transport equipment (SITC 7) & 90.2 & 95.5 & 92.1 & 95.1 \\
\hline Electronic and electrical goods (75+76+77) & 81.0 & 87.7 & 74.6 & 85.7 \\
\hline Transport equipment (78) & 3.7 & 2.3 & 0.7 & 1.8 \\
\hline Other & 9.8 & 4.5 & 3.8 & 3.3 \\
\hline \multicolumn{5}{|c|}{ B: Parts and component share in manufacturing trade } \\
\hline Total manufacturing & 7.5 & 25.6 & 17.9 & 44.4 \\
\hline Machinery and transport equipment (SITC 7) & 6.8 & 24.4 & 46.1 & 73.3 \\
\hline Electronic and electrical goods $(75+76+77)$ & 30.3 & 49.3 & 73.1 & 82.5 \\
\hline Transport equipment & 25.4 & 50.1 & 16.3 & 79.0 \\
\hline Other & 1.4 & 4.0 & 18.0 & 14.4 \\
\hline \multicolumn{5}{|l|}{ C: Trade with East Asia in China's world trade } \\
\hline C.1: Total trade & 55.8 & 33.7 & 21.3 & 28.4 \\
\hline Primary products & 74.6 & 59.2 & 27.9 & 15.5 \\
\hline Manufacturing & 53.3 & 32.2 & 19.9 & 32.7 \\
\hline Machinery and transport equipment (SITC 7) & 53.7 & 33.1 & 13.4 & 32.0 \\
\hline Electronic and electrical goods $(75+76+77)$ & 60.4 & 34.6 & 53.0 & 52.0 \\
\hline Miscellaneous manufacturing (SITC 8) & 50.1 & 29.1 & 27.2 & 36.0 \\
\hline Apparel (84) & 59.1 & 38.1 & 45.1 & 52.9 \\
\hline C2: Parts and component & 60.1 & 44.7 & 22.4 & 38.7 \\
\hline Machinery and transport equipment (SITC 7) & 59.8 & 44.6 & 21.7 & 38.6 \\
\hline Electronic and electrical goods $(75+76+77)$ & 61.2 & 46.0 & 68.9 & 56.2 \\
\hline Transport equipment & 44.2 & 23.2 & 5.6 & 21.7 \\
\hline Miscellaneous manufacturing (SITC 8) & 62.2 & 45.7 & 30.3 & 40.7 \\
\hline
\end{tabular}

Note: 1. East Asia: Developing East Asia and Japan

Source: Compiled from UN Comtrade database. 
Table 5: East Asia - China manufacturing trade

\begin{tabular}{|c|r|r|r|r|}
\hline & \multicolumn{2}{|l|}{$\begin{array}{l}\text { A: Geographic profile } \\
\text { of China's imports }\end{array}$} & \multicolumn{2}{l|}{$\begin{array}{l}\text { B: Exports to China } \\
\text { relative to total exports } \\
\text { by country/region }\end{array}$} \\
\hline & $1994 / 5$ & $2006 / 7$ & $1994 / 5$ & $2006 / 7$ \\
\hline East Asia & 58.2 & 58.6 & 7.6 & 21.2 \\
\hline Japan & 20.9 & 16.4 & 5.5 & 17.3 \\
\hline Developing East Asia & 37.1 & 42.2 & 8.2 & 21.6 \\
\hline Hong Kong & 17.3 & 2.0 & 29.6 & 19.5 \\
\hline Korea & 4.3 & 13.4 & 5.8 & 27.2 \\
\hline Taiwan & 10.7 & 14.0 & 10.3 & 32.6 \\
\hline ASEAN & 3.7 & 13.8 & 2.5 & 13.7 \\
\hline Indonesia & 1.0 & 1.1 & 3.3 & 8.4 \\
\hline Malaysia & 1.1 & 3.4 & 3.2 & 13.5 \\
\hline Philippines & 0.2 & 2.1 & 1.5 & 21.3 \\
\hline Singapore & 0.8 & 2.3 & 1.8 & 12.2 \\
\hline Thailand & 0.7 & 2.3 & 1.8 & 11.2 \\
\hline Vietnam & 0.1 & 0.1 & 2.5 & 4.1 \\
\hline Other countries & 41.8 & 41.4 & 1.5 & 3.7 \\
\hline World & 100 & 100 & 2.7 & 6.7 \\
\hline
\end{tabular}

Source: Compiled from UN Comtrade database, and Trade Data CD-ROM, Council for Economic Planning and Development, Taipei (for data on Taiwan) 
Table 6: Intra-regional shares of Manufacturing Trade: Total, Parts and Components, and Final Trade ( percent), 1992/3 and 2006/07 ${ }^{1}$

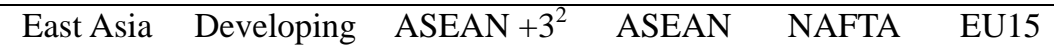

(a) Total trade East Asia

Exports

$1986 / 7$

$1992 / 3$

2006/7

Imports

1986/7

1992/3

2006/7

Trade

(exports + imports)
1986/7

1992/3

2006/7

(b) Parts and components

Exports

1992/3

2006/7

Imports

1992/3

2006/7

Trade

1992/3

2006/7

(c) Final goods ${ }^{2}$

\section{Exports}

1992/3

2006/7

Imports

1992/3

2006/7

Trade

1992/3

2006/7

$\begin{array}{ll}28.4 & 25.1 \\ 47.2 & 38.2 \\ 43.9 & 33.4\end{array}$

48.6

58.2

64.4

$$
22.9
$$

34.9

46.7

$35.8 \quad 24.0$

53.2

55.1

36.5

40.0

50.2

61.1

42.6

53.9

65.9

66.9

35.3

50.9

\section{0}

62.9

38.7

52.1

46.0

36.9

36.8

28.3

55.4

34.7

63.0

42.8

50.3

46.4

35.7

34.0
17.3

15.3

21.9

34.4

43.0

49.3

22.9

27.0

30.4

33.7

35.3

39.6

47.8

35.4

40.2

11.4

17.0

43.4

50.2

25.4

29.1
17.4

20.7

18.4

49.1

44.4

48.1

65.5

61.2

56.9

$11.0 \quad 29.9$

69.7

15.5

36.3

64.1

$20.8 \quad 32.0$

57.9

13.5

37.1

67.5

17.8

39.9

62.6

20.1

38.4

57.4

Notes:

1 Intra-regional trade shares have been calculated excluding bilateral flows between China and Hong Kong.

2 ASEAN + Japan + Korea +China

$2 \quad$ Total (reported) trade (a) - parts and components (b).

Source: Compiled from UN Comtrade database, and Trade Data CD-ROM, Council for Economic Planning and Development, Taipei (for data on Taiwan) 
Table 7: East Asia: Growth of total merchandise exports and imports, 2007Q1-2009Q3 (Year-on-year percent change) ${ }^{1}$

\begin{tabular}{|c|c|c|c|c|c|c|c|}
\hline & 2008Q1 & 2008Q2 & 2008Q3 & 2008Q4 & 2009Q1 & 2009Q2 & 2009Q3 \\
\hline \multicolumn{8}{|l|}{ Exports } \\
\hline East Asia (EA) & 20.6 & 21.0 & 19.3 & -5.6 & -30.1 & -32.5 & -30.2 \\
\hline Japan & 22.9 & 16.4 & 15.2 & -8.1 & -42.1 & -41.1 & -38.2 \\
\hline Developing EA & 19.0 & 21.3 & 19.9 & -4.7 & -26.6 & -27.2 & -24.2 \\
\hline HK & 10.5 & 8.3 & 5.7 & -2.1 & -21.0 & -23.4 & -20.1 \\
\hline China & 21.1 & 22.4 & 23.0 & 4.6 & -20.1 & -22.7 & -20.3 \\
\hline Korea & 17.4 & 23.2 & 27.1 & -9.9 & -24.5 & -20.1 & -20.3 \\
\hline Taiwan & 17.4 & 18.2 & 7.6 & -24.6 & -35.9 & -28.3 & -18.5 \\
\hline ASEAN & 18.9 & 26.9 & 22.9 & -10.3 & -36.8 & -39.3 & 34.2 \\
\hline Indonesia & 31.9 & 29.4 & 27.9 & -5.3 & -32.5 & -33.2 & 31.1 \\
\hline Malaysia & 19.4 & 28.5 & 21.6 & -12.6 & -27.6 & -28.2 & 3.8 \\
\hline Philippines & -2.0 & -0.6 & 2.0 & -22.3 & -33.9 & -36.3 & -37.2 \\
\hline Singapore & 21.7 & 26.4 & 21.2 & -12.9 & -30.7 & -31.2 & -33.2 \\
\hline Thailand & 25.5 & 25.5 & 27.2 & -10.2 & -23.0 & -24.4 & -26.3 \\
\hline Viet Nam & 27.7 & 31.8 & 37.5 & 6.0 & -14.8 & -11.7 & -7.3 \\
\hline \multicolumn{8}{|l|}{ Imports } \\
\hline East Asia (EA) & 29.6 & 29 & 29.8 & -4.1 & -32.5 & -33.1 & 30.7 \\
\hline Japan & 25.6 & 26.8 & 35.8 & 8.3 & -29.0 & -28.5 & -28.1 \\
\hline Developing EA & 29 & 28.9 & 26.6 & -8.0 & -32.1 & -34.2 & -33.2 \\
\hline Hong Kong & 12.0 & 9.6 & 7.0 & -4.0 & -20.8 & -22.3 & -25.2 \\
\hline China & 29.4 & 32.9 & 25.9 & -8.0 & -30.8 & -31.7 & -30.3 \\
\hline Korea & 29.0 & 30.5 & 42.9 & -8.8 & -32.8 & -35.6 & -11.9 \\
\hline Taiwan & 26.1 & 19.2 & 20.3 & -21.9 & -45.9 & -46.3 & -47.2 \\
\hline ASEAN & 37.9 & 36.2 & 32.6 & -5.0 & -37.2 & -36.7 & -35.3 \\
\hline Indonesia & 91.6 & 96.1 & 82.3 & 33.3 & -35.9 & -36.2 & -34.2 \\
\hline Malaysia & 16.1 & 17.3 & 14.5 & -17.1 & -36.8 & -36.1 & 4.8 \\
\hline Philippines & 22.1 & 8.4 & 4.5 & -23.4 & -30.3 & -31.3 & -32.1 \\
\hline Singapore & 32.1 & 35.4 & 32.9 & -9.3 & -30.0 & -28.1 & -29.2 \\
\hline Thailand & 39.6 & 25.7 & 37.8 & 3.8 & -39.7 & -40.5 & -37.3 \\
\hline Vietnam & 69.0 & 61.0 & 22.8 & -8.2 & -36.5 & -34.1 & -31.1 \\
\hline
\end{tabular}


Table 8: China: Growth of total merchandise exports and imports by trading partner countries, 2007Q1 - 2009Q4 (Year-on-year parentage change, current US\$)

\begin{tabular}{|c|c|c|c|c|c|c|c|c|}
\hline & 2008Q1 & $2008 \mathrm{Q} 2$ & 2008Q3 & $2008 Q 4$ & 2009Q1 & $2009 \mathrm{Q} 2$ & 2009 Q3 & $2009 \mathrm{Q} 4^{2}$ \\
\hline \multicolumn{9}{|l|}{ (a) Exports } \\
\hline East Asia (EA) & 23.7 & 25.1 & 28.2 & 4.5 & -23.4 & -24.2 & -18.0 & 8.2 \\
\hline Japan & 12.1 & 18.0 & 18.1 & 7.9 & -16.7 & -23.8 & -16.3 & -6.7 \\
\hline Developing EA & 31.2 & 29.2 & 33.9 & 2.7 & -24.1 & -24.5 & -28.7 & 7.5 \\
\hline Korea & 33.1 & 38.3 & 52.9 & 7.5 & -29.2 & -36.6 & -35.0 & -3.0 \\
\hline Taiwan & 15.4 & 21.1 & 17.3 & -10.4 & -34.5 & -38.8 & -21.4 & 20.1 \\
\hline Hong Kong, China & 10.8 & 6.5 & 11.0 & -9.9 & -24.0 & -21.6 & -16.6 & 12.2 \\
\hline ASEAN & 34.2 & 26.0 & 27.4 & 2.8 & -22.6 & -16.8 & -9.6 & 23.0 \\
\hline Indonesia & 33.2 & 41.5 & 54.8 & 20.2 & -26.4 & -21.0 & -24.0 & 21.3 \\
\hline Malaysia & 33.3 & 28.2 & 20.8 & 7.1 & -23.9 & -12.2 & -9.1 & 9.2 \\
\hline Philippines & 30.4 & 22.8 & 34.5 & 1.3 & -11.8 & -18.7 & -8.5 & 18.6 \\
\hline Singapore & 15.3 & 5.9 & 17.1 & -0.6 & -17.1 & -12.3 & -16.2 & 21.4 \\
\hline Thailand & 37.2 & 42.1 & 38.3 & 5.9 & -27.3 & -29.6 & -14.3 & 21.1 \\
\hline Vietnam & 88.8 & 45.1 & 16.0 & -11.1 & -30.0 & -15.9 & 36.3 & 58.9 \\
\hline USA & 5.4 & 12.2 & 15.3 & 0.7 & -15.4 & -18.5 & -16.7 & 1.4 \\
\hline EU & 25.0 & 29.7 & 23.5 & 4.1 & -22.6 & -26.6 & -23.6 & -4.2 \\
\hline Total export & 16.3 & 19.0 & 20.2 & 0.9 & -21.1 & -23.5 & -20.3 & 7.2 \\
\hline \multicolumn{9}{|l|}{ (b) Imports } \\
\hline East Asia & 18.8 & 24.1 & 13.2 & -18.1 & -33.7 & -23.1 & -12.5 & 30.2 \\
\hline Japan & 17.0 & 23.7 & 18.7 & -5.0 & -29.8 & -21.4 & -13.4 & 15.6 \\
\hline Developing EA & 19.6 & 24.3 & 10.8 & -23.6 & -35.3 & -23.8 & -12.1 & 37.7 \\
\hline Korea & 14.9 & 25.0 & 14.8 & -18.5 & -26.6 & -18.8 & -10.2 & 33.6 \\
\hline Taiwan & 24.5 & 24.2 & 5.0 & -33.3 & -43.9 & -29.9 & -14.9 & 43.8 \\
\hline Hong Kong & 26.0 & -2.5 & 11.0 & -21.4 & -49.1 & -32.9 & -33.3 & -7.7 \\
\hline ASEAN & 19.9 & 23.8 & 12.7 & -18.9 & -33.8 & -22.1 & -8.9 & 12.2 \\
\hline Indonesia & 31.7 & 30.3 & 17.3 & -13.5 & -38.0 & -18.4 & -6.3 & 69.6 \\
\hline Malaysia & 18.4 & 29.5 & 22.4 & -16.1 & -25.0 & -17.0 & -3.5 & 60.3 \\
\hline Philippines & 12.7 & 5.7 & -23.2 & -48.6 & -61.3 & -51.7 & -30.3 & 17.6 \\
\hline Singapore & 6.7 & 35.5 & 27.4 & -9.3 & -23.7 & -28.2 & -11.9 & 27.2 \\
\hline Thailand & 26.0 & 22.9 & 15.8 & -5.6 & -29.2 & -6.6 & -0.9 & 29.7 \\
\hline Vietnam & 64.3 & 19.0 & 69.4 & 6.8 & -7.9 & 23.6 & -8.3 & 47.7 \\
\hline USA & 29.7 & 23.0 & 15.7 & 3.7 & -17.7 & -13.1 & -6.4 & 19.3 \\
\hline EU & 25.9 & 33.0 & 22.7 & 2.3 & -14.7 & -11.2 & -2.2 & 14.9 \\
\hline Total imports & 21.2 & 25.0 & 15.1 & -12.2 & -28.3 & -19.6 & -11.9 & 10.2 \\
\hline
\end{tabular}

1 Growth rates calculated using current US\$ values.

2 Average for October and November.

Source: Compiled from CIEM database 
Table 9: China: Growth of merchandise exports and imports by commodity category, 2008Q1- 2009Q3 (Year-on-year percent change, current US\$)

(a) Exports

Total exports

Primary

Manufacturing

Products of the Chemical or Allied Industries

Plastics and Articles thereof, Rubber and Articles

Textiles and Textile Articles

Footwear, Headgear, Umbrellas, etc

Base Metals \& Articles Of Base Metal

Machinery and Mechanical Appliances, etc (ME)

Electronics

Electrical Machinery and Equipment

Miscellaneous Manufactured Articles

(b) Imports

Total imports

Primary

Manufacturing

Products of the Chemical or Allied Industries

Plastics and Articles thereof, Rubber and Articles

Textiles and Textile Articles

Footwear, Headgear, Umbrellas, etc

Base Metals \& Articles Of Base Metal

Machinery and Mechanical Appliances, etc (ME)

Electronics

Electrical Machinery and Equipment

2008Q1 2008Q2

2008Q3

2008Q4

2009Q1

2009Q2

2009Q3

Miscellaneous Manufactured Articles

$\begin{array}{rrrrrrr}16.3 & 19.0 & 20.2 & 0.9 & -21.1 & -23.5 & -20.3 \\ 16.3 & 24.9 & 29.9 & 8.6 & -17.9 & -13.6 & -14.2 \\ 21.2 & 23.8 & 22.0 & 2.6 & -20.7 & -18.2 & -17.2 \\ 48.5 & 54.0 & 42.2 & 3.1 & -25.2 & -24.9 & -23.4 \\ 13.8 & 10.1 & 16.1 & 10.7 & -21.1 & -17.1 & -17.3 \\ 22.5 & 5.3 & 4.1 & 8.0 & -11.4 & 2.6 & 4.2 \\ 14.7 & 14.4 & 19.7 & 21.3 & -1.3 & 7.2 & 8.2 \\ 23.3 & 18.5 & 26.4 & 22.0 & -9.0 & -1.5 & -4.3 \\ 15.9 & -15.7 & 20.9 & 4.3 & -31.6 & -38.8 & -42.1 \\ 6.2 & 12.5 & 61.5 & 17.2 & -33.5 & -36.5 & -37.3 \\ 20.3 & 27.0 & 20.4 & -1.1 & -21.5 & -19.5 & -20.2 \\ 41.5 & 39.0 & 31.7 & 9.1 & -17.0 & -19.7 & -6.2\end{array}$

41.5

39.0

31.7

2008Q1

2008Q2

2008Q3

$2008 \mathrm{Q} 4$

2009Q2 2009Q3

$\begin{array}{lllllll}21.2 & 25.0 & 15.1 & -12.2 & -28.3 & -19.6 & -11.9\end{array}$

$\begin{array}{lllllll}73.5 & 74.9 & 72.5 & 5.2 & -40.7 & -35.3 & -27.2\end{array}$

$\begin{array}{lllllll}16.3 & 19.1 & 11.4 & -12.1 & -26.2 & -21.1 & -19.2\end{array}$

$\begin{array}{lllllll}19.6 & 23.5 & 19.6 & -10.5 & -23.9 & -18.2 & -16.3\end{array}$

$\begin{array}{rrrrrrr}19.6 & 23.5 & 19.6 & -10.5 & -23.9 & -18.2 & -16.3 \\ 16.3 & 22.5 & 22.7 & -15.6 & -29.2 & -20.1 & 15.2\end{array}$

$\begin{array}{lllllll}6.3 & 2.7 & -3.4 & -9.2 & -22.8 & -22.8 & -23.2\end{array}$

$\begin{array}{rrrrrrr}47.5 & 47.7 & 24.8 & 12.6 & -2.8 & -18.7 & -22.2\end{array}$

$\begin{array}{lllllll}14.1 & 5.8 & 8.3 & -15.0 & -26.3 & -16.9 & -2.7\end{array}$

$\begin{array}{lllllll}11.7 & 18.0 & 9.8 & -10.7 & -24.1 & -17.9 & -8.2\end{array}$

$\begin{array}{lllllll}16.3 & 19.9 & 15.0 & -1.0 & -19.8 & -19.5 & -3.2\end{array}$

$\begin{array}{lllllll}9.5 & 17.1 & 7.4 & -15.2 & -26.3 & -17.4 & -6.7\end{array}$

Source: Compiled from CEIM database. 
Figure 1: Growth of merchandise trade: East Asia, Developing East Asia, China and ASEAN, Jan. 2008 - Nov 2009 (Y-O-Y, percent)

(a) Exports

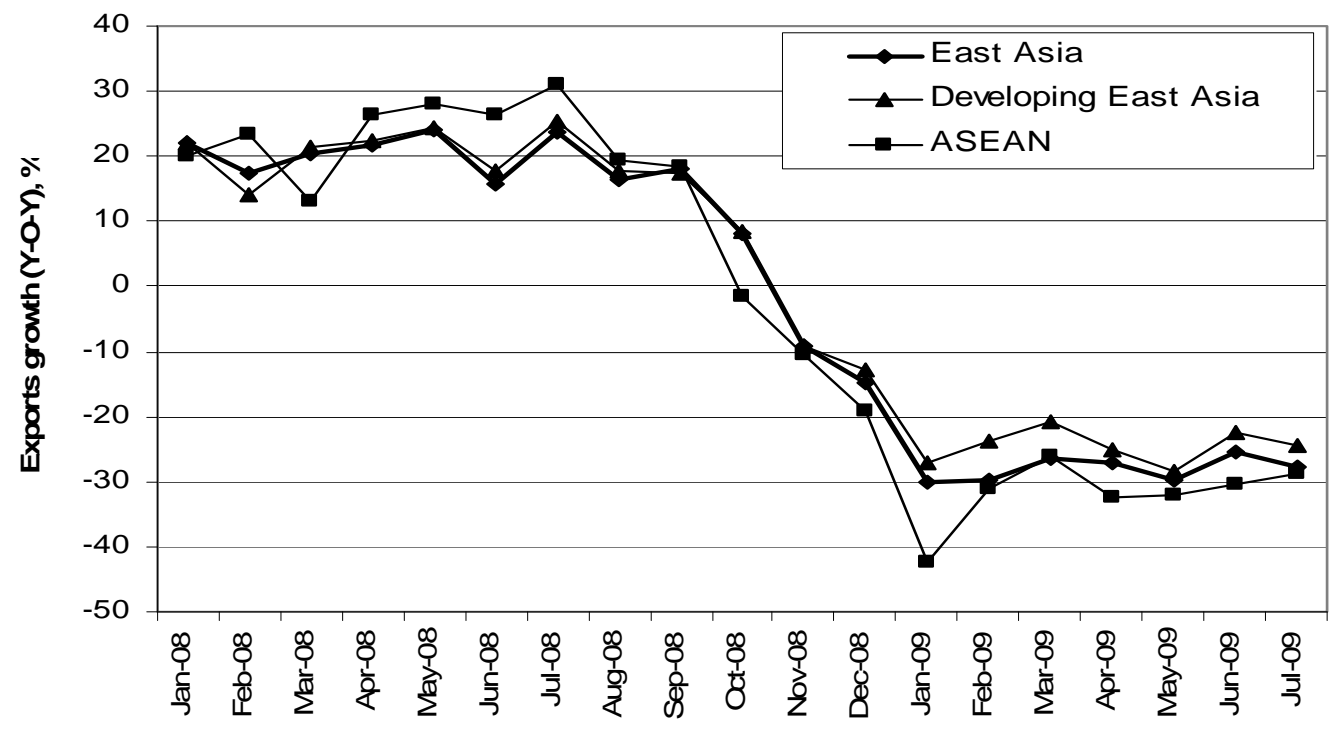

(b) Imports

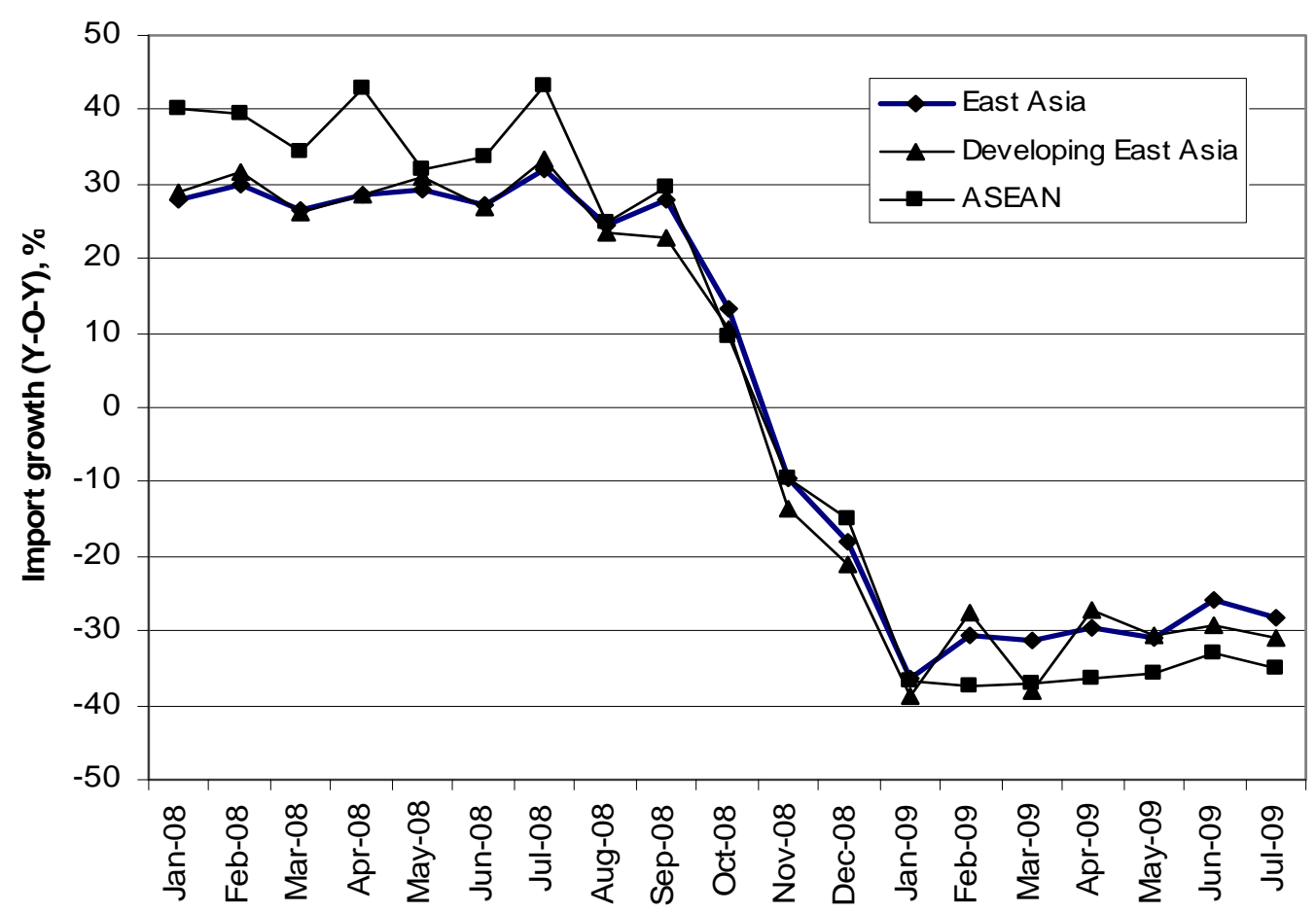

Source: Based on data compiled from CEIM database. 


\section{Working Papers in Trade and Development \\ List of Papers (including publication details as at 2010)}

99/1 K K TANG, 'Property Markets and Policies in an Intertemporal General Equilibrium Model'.

99/2 HARYO ASWICAHYONO and HAL HILL, “Perspiration' v/s 'Inspiration' in Asian Industrialization: Indonesia Before the Crisis'.

99/3 PETER G WARR, 'What Happened to Thailand?'.

99/4 DOMINIC WILSON, 'A Two-Sector Model of Trade and Growth'.

99/5 HAL HILL, 'Indonesia: The Strange and Sudden Death of a Tiger Economy'.

99/6 PREMA-CHANDRA ATHUKORALA and PETER G WARR, ‘Vulnerability to a Currency Crisis: Lessons from the Asian Experience'.

99/7 PREMA-CHANDRA ATHUKORALA and SARATH RAJAPATIRANA, 'Liberalization and Industrial Transformation: Lessons from the Sri Lankan Experience'.

99/8 TUBAGUS FERIDHANUSETYAWAN, 'The Social Impact of the Indonesian Economic Crisis: What Do We Know?'

99/9 KELLY BIRD, 'Leading Firm Turnover in an Industrializing Economy: The Case of Indonesia'.

99/10 PREMA-CHANDRA ATHUKORALA, 'Agricultural Trade Liberalization in South Asia: From the Uruguay Round to the Millennium Round'.

99/11 ARMIDA S ALISJAHBANA, 'Does Demand for Children's Schooling Quantity and Quality in Indonesia Differ across Expenditure Classes?'

99/12 PREMA-CHANDRA ATHUKORALA, 'Manufactured Exports and Terms of Trade of Developing Countries: Evidence from Sri Lanka'.

00/01 HSIAO-CHUAN CHANG, 'Wage Differential, Trade, Productivity Growth and Education.'

00/02 PETER G WARR, 'Targeting Poverty.'

00/03 XIAOQIN FAN and PETER G WARR, 'Foreign Investment, Spillover Effects and the Technology Gap: Evidence from China.'

00/04 PETER G WARR, 'Macroeconomic Origins of the Korean Crisis.'

00/05 CHINNA A KANNAPIRAN, 'Inflation Targeting Policy in PNG: An Econometric Model Analysis.'

00/06 PREMA-CHANDRA ATHUKORALA, 'Capital Account Regimes, Crisis and 
Adjustment in Malaysia.'

00/07 CHANGMO AHN, 'The Monetary Policy in Australia: Inflation Targeting and Policy Reaction.'

00/08 PREMA-CHANDRA ATHUKORALA and HAL HILL, 'FDI and Host Country Development: The East Asian Experience.'

00/09 HAL HILL, 'East Timor: Development Policy Challenges for the World's Newest Nation.'

00/10 ADAM SZIRMAI, M P TIMMER and R VAN DER KAMP, 'Measuring Embodied Technological Change in Indonesian Textiles: The Core Machinery Approach.'

00/11 DAVID VINES and PETER WARR, 'Thailand's Investment-driven Boom and Crisis.'

01/01 RAGHBENDRA JHA and DEBA PRASAD RATH, 'On the Endogeneity of the Money Multiplier in India.'

01/02 RAGHBENDRA JHA and K V BHANU MURTHY, 'An Inverse Global Environmental Kuznets Curve.'

01/03 CHRIS MANNING, 'The East Asian Economic Crisis and Labour Migration: A Set-Back for International Economic Integration?'

01/04 MARDI DUNGEY and RENEE FRY, 'A Multi-Country Structural VAR Model.'

01/05 RAGHBENDRA JHA, 'Macroeconomics of Fiscal Policy in Developing Countries.'

01/06 ROBERT BREUNIG, 'Bias Correction for Inequality Measures: An application to China and Kenya.'

01/07 MEI WEN, 'Relocation and Agglomeration of Chinese Industry.'

01/08 ALEXANDRA SIDORENKO, 'Stochastic Model of Demand for Medical Care with Endogenous Labour Supply and Health Insurance.'

01/09 A SZIRMAI, M P TIMMER and R VAN DER KAMP, 'Measuring Embodied Technological Change in Indonesian Textiles: The Core Machinery Approach.'

01/10 GEORGE FANE and ROSS H MCLEOD, 'Banking Collapse and Restructuring in Indonesia, 1997-2001.'

01/11 HAL HILL, 'Technology and Innovation in Developing East Asia: An Interpretive Survey.'

01/12 PREMA-CHANDRA ATHUKORALA and KUNAL SEN, 'The Determinants of Private Saving in India.'

02/01 SIRIMAL ABEYRATNE, 'Economic Roots of Political Conflict: The Case of Sri Lanka.' 
02/02 PRASANNA GAI, SIMON HAYES and HYUN SONG SHIN, 'Crisis Costs and Debtor Discipline: the efficacy of public policy in sovereign debt crises.'

02/03 RAGHBENDRA JHA, MANOJ PANDA and AJIT RANADE, 'An Asian Perspective on a World Environmental Organization.'

02/04 RAGHBENDRA JHA, 'Reducing Poverty and Inequality in India: Has Liberalization Helped?'

02/05 ARCHANUN KOHPAIBOON, 'Foreign Trade Regime and FDI-Growth Nexus: A Case Study of Thailand.'

02/06 ROSS H MCLEOD, 'Privatisation Failures in Indonesia.'

02/07 PREMA-CHANDRA ATHUKORALA, 'Malaysian Trade Policy and the 2001 WTO Trade Policy Review.'

02/08 M C BASRI and HAL HILL, 'Ideas, Interests and Oil Prices: The Political Economy of Trade Reform during Soeharto's Indonesia.'

02/09 RAGHBENDRA JHA, 'Innovative Sources of Development Finance - Global Cooperation in the $21^{\text {st }}$ Century.'

02/10 ROSS H MCLEOD, 'Toward Improved Monetary Policy in Indonesia.'

03/01 MITSUHIRO HAYASHI, 'Development of SMEs in the Indonesian Economy.'

03/02 PREMA-CHANDRA ATHUKORALA and SARATH RAJAPATIRANA, 'Capital Inflows and the Real Exchange Rate: A Comparative Study of Asia and Latin America.'

03/03 PETER G WARR, 'Industrialisation, Trade Policy and Poverty Reduction: Evidence from Asia.'

03/04 PREMA-CHANDRA ATHUKORALA, 'FDI in Crisis and Recovery: Lessons from the 1997-98 Asian Crisis.'

03/05 ROSS H McLEOD, ‘Dealing with Bank System Failure: Indonesia, 1997-2002.'

03/06 RAGHBENDRA JHA and RAGHAV GAIHA, 'Determinants of Undernutrition in Rural India.'

03/07 RAGHBENDRA JHA and JOHN WHALLEY, 'Migration and Pollution.'

03/08 RAGHBENDRA JHA and K V BHANU MURTHY, 'A Critique of the Environmental Sustainability Index.'

03/09 ROBERT J BAROO and JONG-WHA LEE, 'IMF Programs: Who Is Chosen and What Are the Effects?

03/10 ROSS H MCLEOD, 'After Soeharto: Prospects for reform and recovery in Indonesia.' 
03/11 ROSS H MCLEOD, 'Rethinking vulnerability to currency crises: Comments on Athukorala and Warr.'

03/12 ROSS H MCLEOD, 'Equilibrium is good: Comments on Athukorala and Rajapatirana.'

03/13 PREMA-CHANDRA ATHUKORALA and SISIRA JAYASURIYA, 'Food Safety Issues, Trade and WTO Rules: A Developing Country Perspective.'

03/14 WARWICK J MCKIBBIN and PETER J WILCOXEN, 'Estimates of the Costs of Kyoto-Marrakesh Versus The McKibbin-Wilcoxen Blueprint.'

03/15 WARWICK J MCKIBBIN and DAVID VINES, 'Changes in Equity Risk Perceptions: Global Consequences and Policy Responses.'

03/16 JONG-WHA LEE and WARWICK J MCKIBBIN, 'Globalization and Disease: The Case of SARS.'

03/17 WARWICK J MCKIBBIN and WING THYE WOO, 'The consequences of China's WTO Accession on its Neighbors.'

03/18 MARDI DUNGEY, RENEE FRY and VANCE L MARTIN, 'Identification of Common and Idiosyncratic Shocks in Real Equity Prices: Australia, 1982 to 2002.'

03/19 VIJAY JOSHI, 'Financial Globalisation, Exchange Rates and Capital Controls in Developing Countries.'

03/20 ROBERT BREUNIG and ALISON STEGMAN, 'Testing for Regime Switching in Singaporean Business Cycles.'

03/21 PREMA-CHANDRA ATHUKORALA, 'Product Fragmentation and Trade Patterns in East Asia.'

04/01 ROSS H MCLEOD, 'Towards Improved Monetary Policy in Indonesia: Response to De Brouwer'

04/02 CHRIS MANNING and PRADIP PHATNAGAR, 'The Movement of Natural Persons in Southeast Asia: How Natural?

04/03 RAGHBENDRA JHA and K V BHANU MURTHY, 'A Consumption Based Human Development Index and The Global Environment Kuznets Curve'

04/04 PREMA-CHANDRA ATHUKORALA and SUPHAT SUPHACHALASAI, 'Postcrisis Export Performance in Thailand'

04/05 GEORGE FANE and MARTIN RICHARDSON, 'Capital gains, negative gearing and effective tax rates on income from rented houses in Australia'

04/06 PREMA-CHANDRA ATHUKORALA, 'Agricultural trade reforms in the Doha Round: a developing country perspective'

04/07 BAMBANG-HERU SANTOSA and HEATH McMICHAEL, ' Industrial 
development in East Java: A special case?'

04/08 CHRIS MANNING, 'Legislating for Labour Protection: Betting on the Weak or the Strong?'

05/01 RAGHBENDRA JHA, 'Alleviating Environmental Degradation in the AsiaPacific Region: International cooperation and the role of issue-linkage'

05/02 RAGHBENDRA JHA, RAGHAV GAIHA and ANURAG SHARMA, 'Poverty Nutrition Trap in Rural India'

05/03 PETER WARR, 'Food Policy and Poverty in Indonesia: A General Equilibrium Analysis'

05/04 PETER WARR, 'Roads and Poverty in Rural Laos'

05/05 PREMA-CHANDRA ATHUKORALA and BUDY P RESOSUDARMO, 'The Indian Ocean Tsunami: Economic Impact, Disaster Management and Lessons'

05/06 PREMA-CHANDRA ATHUKORALA, 'Trade Policy Reforms and the Structure of Protection in Vietnam'

05/07 PREMA-CHANDRA ATHUKORALA and NOBUAKI YAMASHITA, 'Production Fragmentation and Trade Integration: East Asia in a Global Context'

05/08 ROSS H MCLEOD, 'Indonesia's New Deposit Guarantee Law'

05/09 KELLY BIRD and CHRIS MANNING, 'Minimum Wages and Poverty in a Developing Country: Simulations from Indonesia's Household Survey'

05/10 HAL HILL, 'The Malaysian Economy: Past Successes, Future Challenges'

05/11 ZAHARI ZEN, COLIN BARLOW and RIA GONDOWARSITO, 'Oil Palm in Indonesian Socio-Economic Improvement: A Review of Options'

05/12 MEI WEN, 'Foreign Direct Investment, Regional Geographical and Market Conditions, and Regional Development: A Panel Study on China'

06/01 JUTHATHIP JONGWANICH, 'Exchange Rate Regimes, Capital Account Opening and Real Exchange Rates: Evidence from Thailand'

06/02 ROSS H MCLEOD, 'Private Sector Lessons for Public Sector Reform in Indonesia'

06/03 PETER WARR, 'The Gregory Thesis Visits the Tropics'

06/04 MATT BENGE and GEORGE FANE, 'Adjustment Costs and the Neutrality of Income Taxes'

06/05 RAGHBENDRA JHA, 'Vulnerability and Natural Disasters in Fiji, Papua New Guinea, Vanuatu and the Kyrgyz Republic'

06/06 PREMA-CHANDRA ATHUKORALA and ARCHANUN KOHPAIBOON, 'Multinational Enterprises and Globalization of R\&D: A Study of U.S-based 
Firms

06/07 SANTANU GUPTA and RAGHBENDRA JHA, 'Local Public Goods in a Democracy: Theory and Evidence from Rural India'

06/08 CHRIS MANNING and ALEXANDRA SIDORENKO, 'The Regulation of Professional Migration in ASEAN - Insights from the Health and IT Sectors'

06/09 PREMA-CHANDRA ATHUKORALA, 'Multinational Production Networks and the New Geo-economic Division of Labour in the Pacific Rim'

06/10 RAGHBENDRA JHA, RAGHAV GAIHA and ANURAG SHARMA, 'On Modelling Variety in Consumption Expenditure on Food'

06/11 PREMA-CHANDRA ATHUKORALA, 'Singapore and ASEAN in the New Regional Division of Labour'

06/12 ROSS H MCLEOD, 'Doing Business in Indonesia: Legal and Bureaucratic Constraints'

06/13 DIONISIUS NARJOKO and HAL HILL, 'Winners and Losers during a Deep Economic Crisis; Firm-level Evidence from Indonesian Manufacturing'

06/14 ARSENIO M BALISACAN, HAL HILL and SHARON FAYE A PIZA, 'Regional Development Dynamics and Decentralization in the Philippines: Ten Lessons from a 'Fast Starter'

07/01 KELLY BIRD, SANDY CUTHBERTSON and HAL HILL, 'Making Trade Policy in a New Democracy after a Deep Crisis: Indonesia

07/02 RAGHBENDRA JHA and T PALANIVEL, 'Resource Augmentation for Meeting the Millennium Development Goals in the Asia Pacific Region'

07/03 SATOSHI YAMAZAKI and BUDY P RESOSUDARMO, 'Does Sending Farmers Back to School have an Impact? A Spatial Econometric Approach’

07/04 PIERRE VAN DER ENG, 'De-industrialisation' and Colonial Rule: The Cotton Textile Industry in Indonesia, 1820-1941'

07/05 DJONI HARTONO and BUDY P RESOSUDARMO, 'The Economy-wide Impact of Controlling Energy Consumption in Indonesia: An Analysis Using a Social Accounting Matrix Framework'

07/06 W MAX CORDEN, 'The Asian Crisis: A Perspective after Ten Years'

07/07 PREMA-CHANDRA ATHUKORALA, 'The Malaysian Capital Controls: A Success Story?

07/08 PREMA-CHANDRA ATHUKORALA and SATISH CHAND, 'Tariff-Growth Nexus in the Australian Economy, 1870-2002: Is there a Paradox?,

07/09 ROD TYERS and IAN BAIN, 'Appreciating the Renbimbi' 
07/10 PREMA-CHANDRA ATHUKORALA, 'The Rise of China and East Asian Export Performance: Is the Crowding-out Fear Warranted?

08/01 RAGHBENDRA JHA, RAGHAV GAIHA AND SHYLASHRI SHANKAR, 'National Rural Employment Guarantee Programme in India - A Review'

08/02 HAL HILL, BUDY RESOSUDARMO and YOGI VIDYATTAMA, 'Indonesia's Changing Economic Geography'

08/03 ROSS H McLEOD, 'The Soeharto Era: From Beginning to End'

08/04 PREMA-CHANDRA ATHUKORALA, 'China's Integration into Global Production Networks and its Implications for Export-led Growth Strategy in Other Countries in the Region'

08/05 RAGHBENDRA JHA, RAGHAV GAIHA and SHYLASHRI SHANKAR, 'National Rural Employment Guarantee Programme in Andhra Pradesh: Some Recent Evidence'

08/06 NOBUAKI YAMASHITA, 'The Impact of Production Fragmentation on Skill Upgrading: New Evidence from Japanese Manufacturing'

08/07 RAGHBENDRA JHA, TU DANG and KRISHNA LAL SHARMA, ‘Vulnerability to Poverty in Fiji'

08/08 RAGHBENDRA JHA, TU DANG, ' Vulnerability to Poverty in Papua New Guinea'

08/09 RAGHBENDRA JHA, TU DANG and YUSUF TASHRIFOV, 'Economic Vulnerability and Poverty in Tajikistan'

08/10 RAGHBENDRA JHA and TU DANG, ‘Vulnerability to Poverty in Select Central Asian Countries'

08/11 RAGHBENDRA JHA and TU DANG, 'Vulnerability and Poverty in Timor- Leste'

08/12 SAMBIT BHATTACHARYYA, STEVE DOWRICK and JANE GOLLEY, 'Institutions and Trade: Competitors or Complements in Economic Development?

08/13 SAMBIT BHATTACHARYYA, 'Trade Liberalizaton and Institutional Development'

08/14 SAMBIT BHATTACHARYYA, 'Unbundled Institutions, Human Capital and Growth'

08/15 SAMBIT BHATTACHARYYA, 'Institutions, Diseases and Economic Progress: A Unified Framework'

08/16 SAMBIT BHATTACHARYYA, 'Root causes of African Underdevelopment'

08/17 KELLY BIRD and HAL HILL, ‘Philippine Economic Development: A Turning Point?' 
08/18 HARYO ASWICAHYONO, DIONISIUS NARJOKO and HAL HILL, 'Industrialization after a Deep Economic Crisis: Indonesia'

08/19 PETER WARR, 'Poverty Reduction through Long-term Growth: The Thai Experience'

08/20 PIERRE VAN DER ENG, ‘Labour-Intensive Industrialisation in Indonesia, 19301975: Output Trends and Government policies'

08/21 BUDY P RESOSUDARMO, CATUR SUGIYANTO and ARI KUNCORO, 'Livelihood Recovery after Natural Disasters and the Role of Aid: The Case of the 2006 Yogyakarta Earthquake'

08/22 PREMA-CHANDRA ATHUKORALA and NOBUAKI YAMASHITA, 'Global Production Sharing and US-China Trade Relations'

09/01 PIERRE VAN DER ENG, ‘'Total Factor Productivity and the Economic Growth in Indonesia'

09/02 SAMBIT BHATTACHARYYA and JEFFREY G WILLIAMSON, 'Commodity Price Shocks and the Australian Economy since Federation'

09/03 RUSSELL THOMSON, 'Tax Policy and the Globalisation of R \& D'

09/04 PREMA-CHANDRA ATHUKORALA, 'China's Impact on Foreign Trade and Investment in other Asian Countries'

09/05 PREMA-CHANDRA ATHUKORALA, 'Transition to a Market Economy and Export Performance in Vietnam'

09/06 DAVID STERN, 'Interfuel Substitution: A Meta-Analysis'

09/07 PREMA-CHANDRA ATHUKORALA and ARCHANUN KOHPAIBOON, 'Globalization of R\&D US-based Multinational Enterprises'

09/08 PREMA-CHANDRA ATHUKORALA, 'Trends and Patterns of Foreign Investments in Asia: A Comparative Perspective'

09/09 PREMA-CHANDRA ATHUKORALA and ARCHANUN KOHPAIBOON,' IntraRegional Trade in East Asia: The Decoupling Fallacy, Crisis, and Policy Challenges'

09/10 PETER WARR, 'Aggregate and Sectoral Productivity Growth in Thailand and Indonesia'

09/11 WALEERAT SUPHANNACHART and PETER WARR, 'Research and Productivity in Thai Agriculture'

09/12 PREMA-CHANDRA ATHUKORALA and HAL HILL, 'Asian Trade: Long-Term Patterns and Key Policy Issues'

09/13 PREMA-CHANDRA ATHUKORALA and ARCHANUN KOHPAIBOON, 'East 
Asian Exports in the Global Economic Crisis: The Decoupling Fallacy and Postcrisis Policy Challenges'.

09/14 PREMA-CHANDRA ATHUKORALA, ‘Outward Direct Investment from India’

09/15 PREMA-CHANDRA ATHUKORALA, 'Production Networks and Trade Patterns: East Asia in a Global Context'

09/16 SANTANU GUPTA and RAGHBENDRA JHA, 'Limits to Citizens' Demand in a Democracy'

09/17 CHRIS MANNING, 'Globalisation and Labour Markets in Boom and Crisis: the Case of Vietnam'

09/18 W. MAX CORDEN, 'Ambulance Economics: The Pros and Cons of Fiscal Stimuli'

09/19 PETER WARR and ARIEF ANSHORY YUSUF, ' International Food Prices and Poverty in Indonesia'

09/20 PREMA-CHANDRA ATHUKORALA and TRAN QUANG TIEN, ‘Foreign Direct Investment in Industrial Transition: The Experience of Vietnam'

09/21 BUDY P RESOSUDARMO, ARIEF A YUSUF, DJONI HARTONO and DITYA A NURDIANTO, 'Implementation of the IRCGE Model for Planning: IRSAINDONESIA15 (Inter-Regional System of Analysis for Indonesia in 5 Regions)

10/01 PREMA-CHANDRA ATHUKORALA, 'Trade Liberalisation and The Poverty of Nations: A Review Article'

10/02 ROSS H McLEOD, 'Institutionalized Public Sector Corruption: A Legacy of the Soeharto Franchise'

10/03 KELLY BIRD and HAL HILL, 'Tiny, Poor, Landlocked, Indebted, but Growing: Lessons for late Reforming Transition Economies from Laos'

10/04 RAGHBENDRA JHA and TU DANG, 'Education and the Vulnerability to Food Inadequacy in Timor-Leste'

10/05 PREMA-CHANDRA ATHUKORALA and ARCHANUN KOHPAIBOON, 'East Asia in World Trade: The Decoupling Fallacy, Crisis and Policy Challenges' 